\title{
July/August 2014
}

Published online: 15 July 2014

(C) Springer Science+Business Media New York 2014

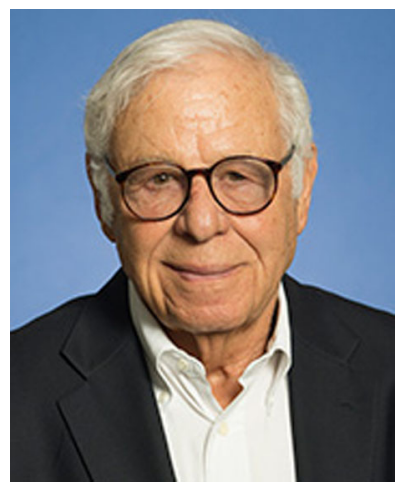

Society celebrates the 85th birthday of Professor Amitai Etzioni, longtime supporter and contributor to its pages. The July/August Symposium is devoted to "The Achievement of Amitai Etzioni" in its many manifestations. Professor Etzioni graciously provided his own reflections on his books and their relation to his scholarly and public vocations:

\section{My Books}

I tried to serve two masters in my writing: my colleagues and my fellow citizens. I attempted to cover the issues that resulted from trying to combine the life of an academic with that of a public intellectual (and sometimes activist) in $M y$ Brother's Keeper: A Memoir and a Message.

The book that got me tenure two years out of school was $A$ Comparative Analysis of Complex Organizations, originally published in 1961. It was, for a while, rather widely cited and led to several hundred studies that contested my theory, supported it, and augmented it. I reviewed those in a revised edition of A Comparative Analysis of Complex Organizations, published in 1975.

The book I consider my best academic achievement is The Active Society.

My first book seeking to advance the cause of peace, in the face of a heating up Cold War and the spread of nuclear weapons was The Hard Way to Peace published in 1962, 10 years after the publication of my A Diary of a Commando Soldier, luckily available only in Hebrew (Befroce Ha Poblziaiong). It was followed with Winning without War in 1964.

I long held that peace requires building communities that are more encompassing than nations. I first studied four such attempts leading to Political Unification (1965) and From Empire to Community (2004).

I raised my liberal communitarian voice first in a book, which some of my fellow citizens read, The Spirit of Community and then some of my colleagues, The New Golden Rule. I applied the idea to specific policy issues in Limits of Privacy. Before that, unaware of the label communitarianism, in Genetic Fix (1973) and above all The Moral Dimension: Toward a New Economics (1988).

Each of the books was preceded and followed by articles on the same general subject, in the everlasting hope to get out the word. Many of these articles can be found at http://ssrn.com/en/. I am not quite done yet-but close. 